\title{
DA POLÍTICA SOCIAL À POLÍTICA PENAL: PARTIDOS POLÍTICOS E PROPOSTAS DE ALTERAÇÃO DO ESTATUTO DA CRIANÇA E DO ADOLESCENTE NA CÂMARA DOS DEPUTADOS
}

FROM SOCIAL POLICY TO CRIMINAL POLICY: POLITICAL PARTIES AND PROPOSED CHANGES TO THE STATUTE OF CHILDREN AND ADOLESCENTS IN THE CHAMBER OF

DEPUTIES

DE LA POLÍTICA SOCIAL A LA POLÍTICA PENAL: PARTIDOS POLÍTICOS Y PROPUESTAS DE ALTERACIÓN DEL ESTATUTO DEL NIÑO Y DEL ADOLESCENTE EN LA CÁMARA DE DIPUTADOS

Marília De Nardin Budó ${ }^{1}$

$1 \quad$ Doutora em Direito pela Universidade Federal do Paraná. Mestre em Direito pela Universidade Federal de Santa Catarina. Especialista em Pensamento político brasileiro pela Universidade Federal de Santa Maria. Graduada em direito e jornalismo pela Universidade Federal de Santa Maria. Professora do Programa de Pós-graduação em Direito da Faculdade Meridional, em Passo Fundo, Rio Grande do Sul. E-mail:mariliadb@yahoo.com.br. 
Resumo: Dada a mudança de paradigma que caracteriza o tratamento jurídico da criança e do adolescente a partir de 1988 no Brasil, este trabalho investiga o panorama das propostas legislativas sobre o Estatuto da Criança e do Adolescente durante dez anos. Por meio de análise quanti-qualitativa das propostas, e segundo o marco teórico da criminologia crítica, identifica se são as políticas sociais ou as políticas penais que têm sido contempladas com o maior número de iniciativas legislativas. Também identifica como ocorre a relação entre os tipos de proposições e os partidos políticos a que pertencem os proponentes. Os resultados indicam uma preponderância das políticas penais, para recrudescer a repressão, de um lado, a adultos que vitimizam crianças; e, de outro lado, a adolescentes em conflito com a lei, com preponderância dos partidos de esquerda nas primeiras, e dos partidos de direita nas segundas. Essa tendência contribui para a inversão de prioridades e para a reprodução social das desigualdades.

Palavras-chave: Populismo penal. Criminologia crítica. Estatuto da Criança e do Adolescente. Proteção integral. Comportamento legislativo.

Abstract: Given the paradigm shift that has characterized the legal treatment of children and adolescents since 1988 in Brazil, this paper investigates the panorama of legislative proposals on the Statute of Children and Adolescents over a ten-year period. Through quantitative and qualitative analysis of the proposals, and based on the theoretical framework of critical criminology, it identifies which policies had the highest number of legislative initiatives: social or political. It also determines the link between the types of propositions and the political parties to which the proposers belonged. The results indicate a predominance of criminal policies aimed at repressing, on one hand, adults who victimize children; and on the other, adolescents who come into conflict with the law. There was a predominance of left-wing parties in the first, and of right-wing parties in the second. This trend contributes to the reversal of priorities, and the social reproduction of inequalities. 
Keywords: Penal populism. Critical criminology. Statute of the Child and Adolescent. Integral protection. Legislative behavior.

Resumen: Dado el cambio de paradigma que caracteriza el tratamiento jurídico del niño y del adolescente a partir de 1988 en Brasil, este trabajo estudia el panorama de las propuestas legislativas sobre el Estatuto del Niño y del Adolescente a lo largo de diez años. Por medio de un análisis cuantitativo y cualitativo de las propuestas, y de acuerdo al marco teórico de la criminología crítica, se identifica si fueron las políticas sociales o las políticas penales las que fueron contempladas con un mayor número de iniciativas legislativas. También se identifica como ocurre la relación entre los tipos de proposiciones y los partidos políticos a los que pertenecen los proponentes. Los resultados indican, por un lado, una preponderancia de las políticas penales para recrudecer la represión de adultos que victimizan a los niños; y por otro lado, a adolescentes en conflicto con la ley, con preponderancia de los partidos de izquierda en las primeras, y de los partidos de derecha en las segundas. Esa tendencia contribuye a la inversión de prioridades y a la reproducción social de las desigualdades.

Palabras clave: Populismo penal. Criminología crítica. Estatuto del Niño y del Adolescente. Protección integral. Comportamiento legislativo.

\section{INTRODUÇÃO}

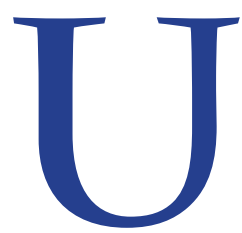

ma das principais críticas que se costuma realizar ao direito da criança e do adolescente nos dias atuais é a sua crise de efetividade. É fato que, a despeito das duas décadas e meia de vigência, o Estatuto da Criança e do Adolescente sofre uma profunda dificuldade de ser implementado, sobretudo no que tange às políticas sociais. Junto a essa análise conjuntural, é possível identificar como possíveis causas dois grandes fantasmas: 
de um lado, a permanência discursiva da doutrina menorista típica do final do século XIX; de outro lado, o crescente punitivismo em que estão envoltas boa parte das propostas políticas das últimas duas décadas.

Para compreender essas dificuldades, este trabalho traz um estudo quantiqualitativo sobre a mobilização legislativa pela alteração do Estatuto em um período de dez anos (2003-2012) na Câmara dos Deputados. O objetivo é o de comparar políticas sociais e políticas penais, bem como sua relação com os partidos políticos a que pertencem os proponentes. O problema de pesquisa foi assim formulado: que tipo de política pública prepondera nas propostas de alteração do Estatuto da Criança e do Adolescente na Câmara dos Deputados $(C D)$ em um período de dez anos, especialmente no que tange à relação entre políticas sociais e políticas penais? Há influência do alinhamento ideológicopartidário na escolha do tipo de política pública adotada?

Entende-se que a crise de interpretação do Estatuto não passa apenas pelos órgãos de sua aplicação, tais como as agências executivas do sistema e o Poder Judiciário. Por isso, ela opta por focar a análise na atuação do Parlamento, órgão que tem a possibilidade de alterar a lei, tanto para melhorar suas possibilidades de implementação, quanto para modificar completamente as suas bases teóricas e principiológicas.

O trabalho parte do marco teórico da Criminologia crítica, partindo de dois pressupostos fundamentais a respeito do processo de construção social da criminalidade: 1) crime e desvio resultam de processos de criminalização, desde a definição da norma até sua atribuição aos indivíduos que a desobedecem²; 2) os processos de criminalização não são aleatórios, obedecendo a uma lógica maior dentro das estruturas econômicas de poder na sociedade capitalista, tendo como principal resultado a reprodução social das desigualdades ${ }^{3}$. No processo de criminalização primária, a agência política do sistema penal protagoniza a definição em abstrato dos crimes e das penas, utilizando, em grande medida nos últimos tempos, essa prerrogativa como forma de se autopromover diante de uma sociedade insegura e amedrontada.

2 BECKER, Howard. Outsiders: Studies in the sociology of deviance. New York: The Free Press, 1996.

3 BARATTA, Alessandro. Criminologia crítica e crítica do direito penal. 3. ed. Tradução de Juarez Cirino dos Santos. Rio de Janeiro: Revan/ICC, 2002. 
Para expor os resultados do estudo, o artigo divide-se em três partes. $\mathrm{Na}$ primeira, realiza-se revisão bibliográfica sobre o paradigma da proteção integral adotado pela legislação brasileira. Na segunda, são apresentados os resultados da pesquisa quanti-qualitativa dos projetos de lei. Na terceira parte, os resultados são analisados e discutidos.

\section{O PARADIGMA DA PROTEÇÃO INTEGRAL: MAIS POLÍTICA SOCIAL, MENOS POLÍTICA PENAL}

A emergência do Estatuto da Criança e do Adolescente, no ano de 1990, precedido pela Constituição Federal de 1988 e pela Convenção Internacional dos Direitos da Criança, de 1989, costuma ser apontada como uma importante ruptura de paradigma na área da infância e da juventude ${ }^{4}$. De maneira muito singular na história do Brasil, essa mudança não foi uma imposição do Estado, mas sim o resultado de lutas populares nascidas sob a vigência do Código de Menores 5 .

Sem deixar de lado o mundo jurídico e o mundo ligado às políticas sociais da época, não há dúvidas de que o grande responsável pela mudança foram os movimentos sociais em um clima democrático propício. Além deles, as rebeliões dos próprios meninos e meninas privados de liberdade na Fundação de Bem-Estar do Menor (FEBEM) foram fundamentais para uma mudança na compreensão do que se estava fazendo e do que se deveria fazer em relação a esses adolescentes, difundindo-se a bandeira da desinstitucionalização6 ${ }^{6}$. A adoção da doutrina de proteção integral seria um pressuposto para essa luta.

A doutrina da proteção integral está construída sobre dois pilares, a superação do "menor em situação irregular" como objeto de tutela do Estado, para dar lugar

4 CUSTÓDIO, André Viana. Teoria da proteção integral: pressuposto para compreensão do direito da criança e do adolescente. Revista do Direito, v. 29, p. 22-43, Santa Cruz do Sul, 2008.

5 GARCÍA MÉNDEZ, Emilio; COSTA, Antonio Carlos Gomes. Das necessidades aos direitos. São PauIo: Malheiros, 1994.

6 Irene e Irma Rizzini observam que, em 1987, o governo buscou salvar a FUNABEM, por meiode uma tentativa de rever seus paradigmas, o que não resultou, porém, no avanço que se buscava: manteve-se "a lógica de que, internando-se o menor carente, evitava-se o abandonado, e, por sua vez, o infrator". RIZZINI, Irene; RIZZINI, Irma. A institucionalização de crianças no Brasil: Percurso histórico e desafios do presente. Rio de Janeiro: PUC-Rio; São Paulo: Loyola, 2004. p. 47. 
à concepção da criança e do adolescente como sujeitos de direitos; e a afirmação de sua condição peculiar de pessoa em desenvolvimento. Suas características específicas são consideradas em toda a sua amplitude, que é biológica, social, cultural, etc. ${ }^{7}$. Se crianças e adolescentes passam a ser agora sujeitos de direitos, não são mais admissíveis políticas e medidas que, sob o pretexto de proteger, vulnerem ou restrinjam direitos, algo muito frequente na perspectiva tutelar e menorista ${ }^{8}$. A absoluta prioridade e o respeito ao princípio do melhor interesse da criança fundamentam essa doutrina, implicando que somente o que seja considerado direito pode ser de seu "interesse superior" 9 .

Como observa García Méndez, as dificuldades de implementação dessa principiologia não se resumem às questões estruturais: talvez a mais tormentosa de todas seja o problema de interpretação ${ }^{10}$. O Estatuto está fundado em três eixos centrais, denominados sistemas de garantias. São eles: o sistema primário de garantias, com foco em toda a população infanto-juvenil brasileira, voltado às políticas sociais; o sistema secundário de garantias, que "tem como foco a criança e o adolescente enquanto vitimizados, enquanto vulnerados em seus direitos fundamentais", direitos que não se resumem à vida e à integridade física, mas também à liberdade de expressão, à saúde, à educação, etc.; e o sistema terciário de garantias o qual tem por objetivo descrever o ato infracional e as medidas socioeducativas ao adolescente em conflito com a lei ${ }^{11}$. Na leitura de Baratta, seria possível desenhar esse sistema em uma pirâmide, que demonstra não apenas as diferentes políticas que sustentam a doutrina da proteção integral, mas também os níveis e os espaços efetivamente destinados a cada uma delas:

A parte mais ampla está representada pelas políticas sociais básicas (escola, saúde). No segundo nível encontram-se as políticas de ajuda social (medidas

7 MAUGER, Gérard, Juventude: idades da vida e gerações. Dados [on-line], v. 56, n.1, 2013, pp. 169-183. Disponível em: <http://www.scielo.br/scielo.php?script=sci_arttext\&pid=S0011-52582013000100007\&lng=es\&nrm=iso>. Acesso em: 07 jan. 2014.

8 CORTÉS MORALES, Julio. A 100 años de la creación del primer Tribunal de Menores y 10 años de la Convención Internacional de los Derechos del Niño: el desafío pendiente. In: UNICEF. Justicia y derechos del niño, n. 9. Santiago, Chile: 2007. p. 143-158.

9 CILLERO BRUÑOL, Miguel. El interés superior del niño en el marco de la convención internacional sobre los derechos del niño. In: UNICEF. Justicia y derechos del niño, n. 9. Santiago, Chile: 2007. p. 125-142.

10 GARCÍA MÉNDEZ, Emilio. Infancia, ley y democracia: una cuestión de justicia. In: UNICEF. Justicia y derechos del niño, n. 9. Santiago, Chile: 2007. p. 27-47.

11 SARAIVA, João Batista Costa. Compêndio de direito penal juvenil. 4. ed. Porto Alegre: Livraria do Advogado, 2010. p. 64. 
de proteção em sentido estrito); mais acima as políticas correccionais (medidas socioeducativas de resposta à delinquência juvenil); finalmente, encontram-se as políticas institucionais que se referem à organização administrativa e judicial, ou seja, aos direitos processuais fundamentais das crianças ${ }^{12}$.

Para a implementação real da doutrina da proteção integral, o passo mais importante é o que alavanca direitos sociais. Já as medidas de proteção e as medidas correcionais são secundárias e subsidiárias. A organização do Estatuto obedece a essa lógica, de modo que as medidas socioeducativas, regulamentadas no Brasil nos arts. 112 a 125, têm na base a responsabilização, buscando expurgar do ordenamento a pura e simples repressão de crianças e adolescentes. Nessa legislação há a possibilidade de remissão, prevista nos arts. 126 a 128, no intuito de evitar toda a sorte de malefícios que a aplicação de uma sanção, em especial a de internação, pode causar à identidade do adolescente ${ }^{13}$.

Apesar de mantida a possibilidade de privação de liberdade do adolescente, ela é subsidiária, jamais vista como um bem em si, e reservada taxativamente a três situações: tratar-se de ato infracional cometido mediante grave ameaça ou violência à pessoa; por reiteração no cometimento de outras infrações graves; por descumprimento reiterado e injustificável da medida anteriormente imposta ${ }^{14}$. Ainda assim, ao Juiz é facultada a aplicação da medida, pois tais requisitos são necessários, mas não suficientes para privar a o adolescente de liberdade ${ }^{15}$.

Contudo a implementação das políticas sociais básicas vem conflitando com o sistema econômico hegemônico na atualidade, de modo que os níveis assistencial e correcional dessa legislação parecem ser encarados como prioridade ${ }^{16}$. Nas práticas judiciais e nos discursos políticos percebem-se, de um lado, representações sobre a criança e o adolescente que retrocedem ao início do século XIX, quando eram equiparados a adultos em miniatura e, de outro lado,

12 BARATTA, Alessandro. Os direitos da criança e o futuro da democracia. p. 63.

13 GOFFMAN, Erving. Manicômios, prisões e conventos. Tradução de Dante Moreira Leite. 7. ed. São Paulo: Perspectiva, 2001.

14 BRASIL. Lei n 8.069 de 13 de julho de 1990. Dispõe sobre o Estatuto da Criança e do Adolescente e dá outras providências. Disponível em: <http://www.planalto.gov.br/ccivil_03/Leis /L8069.htm>. Acesso em: 20 jun. 2014.

15 FRASSETO, Flávio Américo. Ato infracional, medida socioeducativa e processo: a nova jurisprudência do STJ. Discursos sediciosos: crime, direito e sociedade, ano 7, n. $12,2^{\circ}$ sem. 2002, p. $167-191$.

16 BARATTA, Alessandro. Os direitos da criança e o futuro da democracia. p. 63. 
um regresso ao final do século XIX, com uma perspectiva fortemente tutelar ${ }^{17}$. A ideia de que o foco do direito é a criança e o adolescente em "situação de risco" e em situação de "vulnerabilidade social" ressuscita o velho binômio "criança em perigo - criança perigosa", que predominou durante a ditadura militar com a Política Nacional de Bem-Estar do Menor ${ }^{18}$.

Nessa conjuntura, outros elementos se inserem para dificultar ainda mais a implementação das políticas sociais de base do Estatuto: nos últimos vinte anos, o Brasil vem vivenciando um grande encarceramento, tanto de adultos quanto de adolescentes. A população carcerária triplicou nos últimos quinze anos ${ }^{19}$, a de adolescentes internados duplicou entre 1996 e $2013^{20}$. Afora isso, o número de adolescentes negros e pobres vítimas de homicídio também se encontra em franco crescimento, o que traz diversas questões ao debate, sobretudo, a real função do recrudescimento de políticas penais em detrimento de políticas sociais ${ }^{21}$. Sucessivos pânicos morais a identificarem os adolescentes das periferias como os grandes inimigos da sociedade vêm caracterizando a realidade atual, desde

17 Cf. BUDÓ, Marília De Nardin. Mídias e discursos do poder: a legitimação discursiva do processo de encarceramento da juventude pobre no Brasil. Tese (Doutorado). Programa de Pós-graduação em Direito, Universidade Federal do Paraná, Curitiba, 2013. 542 f. MIRAGLIA, Paula. Aprendendo a lição: uma etnografia das Varas Especiais da Infância e da Juventude. Novos Estudos, n. 72, jul. 2005. p. 79-98. CIARALLO, Cynthia R. C. A.; ALMEIDA, Ângela Maria de O. Conflito entre práticas e leis: a adolescência no processo judicial. Fractal: Revista de Psicologia, v. 21, n. 3, p. 613-630, set./dez. 2009.

18 BUDÓ, Marília De Nardin. Mídias e discursos do poder: a legitimação discursiva do processo de encarceramento da juventude pobre no Brasil.

19 Os dados do Ministério da Justiça demonstram que em 2000 havia 232.755 pessoas presas. BRASIL. Ministério da Justiça. Departamento penitenciário Nacional. População carcerária sintético: nov. 2000. Disponível em: <http://www.justica.gov.br/sua-seguranca/departamento-penitenciario-nacional/ sistema-prisional/anexos-sistema-prisional/populacao-carceraria-sintetico-2000.pdf>. Acesso em: 20 mar. 2013. Em 2014, somavam 563.526, 711.463 se considerados os presos em prisão domiciliar. CNJ - CONSELHO NACIONAL DE JUSTIÇA. Departamento de Monitoramento e Fiscalização do Sistema Carcerário e do Sistema de Execução de Medidas Socioeducativas. Novo diagnóstico de pessoas presas no Brasil. Brasília: 2014. Disponível em: <http://www.cnj.jus.br/images/imprensa/diagnostico_ de_pessoas_presas_correcao.pdf>. Acesso em: 20 jul. 2014.

20 Já os dados da Secretaria de Direitos Humanos, do governo federal, indica que, em 1996, havia cerca de 4250 adolescentes com restrição e privação de liberdade. BRASIL. Secretaria de Direitos Humanos. Atendimento socioeducativo ao adolescente em conflito com a lei: Levantamento nacional 2011. Disponivel em: <http://www.sdh.gov.br/assuntos/criancas-e-adolescentes/pdf/SinaseLevantamento2011.pdf>. Acesso em: 25 jul. 2013.Em 2013, eles já somavam mais de 20.081. CNMP - CONSELHO NACIONAL DO MINISTÉRIO PÚBLICO. Relatório da Infância e Juventude - Resolução $n^{\circ}$ 67/2011: Um olhar mais atento às unidades de internação e semiliberdade para adolescentes. Brasília: Conselho Nacional do Ministério Público, 2013. Disponível em: <http://www.cnmp.mp.br/portal/images/stories/Noticias /2013/Arquivos/Relat\%C3\%B3rio_Interna\%C3\%A7\%C3\%A3o.PDF>. Acesso em: 20 abr. 2014.

21 WAISELFISZ, JulioJacobo. Mapa da violência 2014: os jovens do Brasil. Rio de Janeiro: FLACSO, 2014. Disponível em: <http://www.mapadaviolencia.org.br/pdf2014/Mapa2014_JovensBrasil_Preliminar.pdf>. Acesso em: 15 mar. 2015. 
o discurso dos veículos hegemômicos de comunicação até o próprio discurso político ${ }^{22}$. De fato, além de priorizar a punição em detrimento da garantia dos direitos, a lei também é descumprida no que tange a princípios básicos, como o princípio de igualdade ${ }^{23}$. Adolescentes negros estão sobrerrepresentados nas estatísticas de internação, bem como nas de vítimas de homicídio no Brasil24.

Para compreender de que maneira o direito da criança e do adolescente vem se desenvolvendo nesse contexto, sobretudo no que tange à compreensão política de seus princípios e significados, a próxima seção trará os resultados da pesquisa documental realizada nos projetos de lei da Câmara dos Deputados. Considerando o desenho da pirâmide da doutrina da proteção integral em níveis, que reserva à condição de secundárias e minoritárias a correção e a repressão aos adolescentes em conflito com a lei, destinando às políticas sociais básicas a maior atenção, questiona-se: as políticas de alteração do Estatuto da Criança e do Adolescente elaboradas pelos deputados federais nos últimos dez anos têm respeitado tal estrutura?

\section{O UNIVERSO DAS PROPOSTAS DE ALTERAÇÃO DO ESTATUTO DA CRIANÇA E DO ADOLESCENTE: MENOS POLÍTICA SOCIAL, MAIS POLÍTICA PENAL}

Para compreender a movimentação legislativa sobre a criança e o adolescente nos últimos dez anos na Câmara dos Deputados, foram analisados os projetos de lei resultantes do termo de busca "Estatuto da Criança e do Adolescente", no site da referida casa legislativa. O resultado, filtrado no período de 01 de janeiro de 2003 a 31 de dezembro de 2012, foi de 314 propostas. A partir desse dado, analisaram-se os sentidos em que essas propostas se dirigiam, diante da pirâmide das políticas públicas exigida pela doutrina da proteção integral. Tais

22 BUDÓ, Marília de Nardin . Sobre bruxas e monstros pueris: do medo ao controle. In: Monica Ovinski de Camargo Cortina e Valter Cimolin. (Org.). Criminologia crítica. 1. ed.Curitiba: Multidéia, 2015, v. 2, p. 75-100.

23 FLAUZINA, Ana Lucia Pinheiro. Corpo negro caído no chão: o sistema penal e o projeto genocida do Estado brasileiro. Rio de Janeiro: Contraponto, 2008.

24 WAISELFISZ, JulioJacobo. Mapa da violência 2014: os jovens do Brasil. Rio de Janeiro: FLACSO, 2014. Disponível em: <http://www.mapadaviolencia.org.br/pdf2014/Mapa2014_JovensBrasil_Preliminar.pdf>. Acesso em: 15 mar. 2015. 
propostas foram selecionadas apenas dentre aquelas de iniciativa dos deputados federais, propostas individual ou coletivamente. Foram incluídos na análise apenas os projetos de lei, excluindo-se as propostas de emenda constitucional. Isso significa que as propostas visando à redução da maioridade penal não aparecem na população analisada, mas apenas projetos de lei intencionados a modificar, de qualquer maneira, o Estatuto da Criança e do Adolescente. A escolha da temporalidade deu-se em razão da necessidade de visualizar as flutuações de propostas em um tempo relativamente longo, de maneira que fosse possível comparar legislaturas diferentes.

Foram analisados todos os 314 projetos de lei selecionados segundo esses critérios, catalogados segundo as seguintes variáveis: número da proposta, autor da proposta, sexo do autor da proposta, seu partido, tipo de política pública, categoria, situação e data. Apresenta-se, a seguir, um mapeamento das propostas, categorizando-as e quantificando-as, de maneira a se apresentar uma abordagem quanti-qualitativa do corpus de pesquisa.

\section{APRESENTAÇÃO DAS VARIÁVEIS}

As variáveis são preponderantemente nominais, com exceção da data de apresentação do projeto. Em razão disso, os dados apresentados não trazem importantes análises estatísticas, mas principalmente análises de frequência.

Enquanto algumas delas são facilmente compreensíveis, como número, autor, sexo, partido e data, outras merecem uma explicação mais aprofundada. É o caso das variáveis "categoria" (composta pelos valores: conselhos tutelares; deveres; direitos; educação; trabalho; saúde; família; prevenção geral; prevenção especial; política de atendimento; medidas protetivas; medidas socioeducativas diferentes da internação; infracionalização; situação de rua; procedimentos; criminalização; infração administrativa; questões administrativas; outros) e "tipo de política pública" (composta pelos valores: política penal e política social). 


\section{VARIÁVEL “CATEGORIA”}

Ao longo da análise, os projetos foram sendo classificados em categorias, criadas conforme o título, capítulo ou seção do ECA em que estaria inserido o artigo de lei que deveria ser alterado, revogado ou criado. As categorias estão explicadas e quantificadas no Quadro $1^{25}$ :

QUADRO 1: Categorias de análise dos projetos.

\begin{tabular}{|c|c|c|}
\hline Categoria & $\mathrm{N}^{\circ}$ & Descrição \\
\hline Conselhos tutelares & 39 & $\begin{array}{l}\text { Alteram, revogam ou incluem novos artigos ao ECA no tema dos conselhos } \\
\text { tutelares, em especial quanto à sua composição, método de ingresso, } \\
\text { remuneração e (im)possibilidade de recondução. A localização no ECA é o } \\
\text { Título V - arts. } 131 \text { a } 140 \text {. }\end{array}$ \\
\hline Deveres & 03 & Criam deveres da criança e do adolescente, como contrapartida aos direitos. \\
\hline Direitos & 06 & Ampliam os direitos da criança e do adolescente já existentes no ECA. \\
\hline Educação & 08 & $\begin{array}{l}\text { Relacionados ao exercício dos direitos previstos no Capítulo IV do Título II: } \\
\text { Do Direito à Educação, à Cultura, ao Esporte e ao Lazer. }\end{array}$ \\
\hline Trabalho & 10 & Dispõem sobre a regulamentação do trabalho educativo. \\
\hline Saúde & 09 & $\begin{array}{l}\text { Garantem o acesso à saúde física e mental da gestante, da criança e do } \\
\text { adolescente. }\end{array}$ \\
\hline Família & 18 & $\begin{array}{l}\text { Projetos sobre família natural - reconhecimento de paternidade, p. ex. - e } \\
\text { família substituta - adoção, guarda e tutela. }\end{array}$ \\
\hline Prevenção geral & 15 & $\begin{array}{l}\text { A prevenção está localizada no Título III da Parte Geral do ECA e se divide } \\
\text { em prevenção geral e prevenção especial. Dividiu-se da mesma maneira } \\
\text { nesta análise, constando em prevenção geral os projetos relacionados à } \\
\text { ameaça ou à violação de direitos. }\end{array}$ \\
\hline Prevenção especial & 34 & $\begin{array}{l}\text { Todos os projetos que versam sobre quaisquer temas contidos no Título III, } \\
\text { Parte Geral, dividida em três seções no ECA: Da informação, Cultura, Lazer, } \\
\text { Esportes, Diversões e Espetáculos; Dos Produtos e Serviços; Da Autorização } \\
\text { para Viajar. }\end{array}$ \\
\hline
\end{tabular}

25 É importante observar que dos 314 PLs, dezesseis poderiam pertencer a mais de uma categoria. Os principais exemplos são aqueles em que se cria uma proibição, na categoria prevenção especial e, a seguir, cria-se uma infração administrativa como sanção àquele que descumprir a proibição. Em razão da dificuldade em trabalhar com esses dados com respostas múltiplas, além da pouca representatividade estatística desses PLs pluricategorizáveis, optou-se por incluí-los em apenas uma categoria, entendida como predominante. No exemplo acima, os PLs foram categorizados apenas como prevenção especial. 


\begin{tabular}{lcl}
\hline $\begin{array}{l}\text { Política de } \\
\text { atendimento }\end{array}$ & 03 & $\begin{array}{l}\text { Projetos que tratam sobre a política de atendimento (Título I, Parte Especial), } \\
\text { principalmente das instituições de atendimento. }\end{array}$ \\
\hline Medidas protetivas & 03 & $\begin{array}{l}\text { Tratam das medidas de proteção contidas no Título II da Parte Especial do } \\
\text { ECA. }\end{array}$ \\
\hline $\begin{array}{l}\text { Medidas } \\
\text { socioeducativas } \\
\text { diferentes da } \\
\text { internação }\end{array}$ & 07 & $\begin{array}{l}\text { Projetos sobre medidas em meio aberto e medida de semiliberdade, em } \\
\text { especial os projetos que tratam sobre a inserção do trabalho educativo. }\end{array}$ \\
\hline $\begin{array}{l}\text { Infracionalização } \\
\text { Projetos de lei que possuem um profundo caráter repressivo, buscando } \\
\text { recrudescer a medida socioeducativa de internação por emio da ampliação } \\
\text { dos prazos de internação, tanto daquela decorrente de sentença judicial, } \\
\text { quanto da internação provisória. }\end{array}$ \\
\hline
\end{tabular}

\section{Medida}

socioeducativa

de Internação:

07

Garantia de direitos aos adolescentes internados, bem como melhoria das

direitos, garantias, condições de cumprimento da medida.

condições

\begin{tabular}{lll}
\hline Situação de rua $\quad 04 \quad \begin{array}{l}\text { Tratam sobre a restrição do direito de ir e vir de crianças e adolescentes } \\
\text { desacompanhados à noite. }\end{array}$
\end{tabular}

Procedimentos 05 Procedimentos especiais previstos no Capítulo III do Título VI do ECA.
Criminalização
65
Buscam alterar, revogar ou adicionar artigo ao Capítulo I do Título VII do ECA, onde estão localizados os crimes e as penas. Trata-se dos arts. 225 a 244-B.

\begin{tabular}{lcl}
\hline Descriminalização & 01 & Descriminaliza conduta prevista como crime pelo ECA. \\
\hline $\begin{array}{l}\text { Infração } \\
\text { administrativa }\end{array}$ & 18 & $\begin{array}{l}\text { Alteram, revogam ou adicionam artigo ao Capítulo II do Título VII do ECA, } \\
\text { onde se localizam as infrações administrativas (arts. 245 a 258-B). }\end{array}$
\end{tabular}

Questões

12

administrativas

Outros
Alteram, revogam ou criam artigos a respeito das doações aos fundos dos direitos da criança e do adolescente nacional, distrital, estadual ou municipal, provenientes da dedução do imposto de renda.

Fonte: Elaboração própria. 


\section{VARIÁVEL "POLÍTICA PÚBLICA"}

Esta variável foi elaborada a partir de agrupamentos da variável categoria para buscar diferenciar os projetos de lei que utilizam a face repressiva do Estado daqueles que levam a cabo projetos de política social. Foram criados, então, três valores para essa variável: política penal, política social e outros. A maior parte dos projetos não dizia respeito nem a uma nem a outra política, e se tornaram valores dispensáveis para a análise pretendida dessa variável.

No valor política penal (PP) foram inseridos os projetos de lei buscando criminalizar condutas, contidos na categoria criminalização (doravante tratada pela sigla PP1) e também aqueles intencionando recrudescer a repressão a adolescentes autores de atos infracionais, ou seja, aqueles contidos na categoria infracionalização (doravante tratada pela sigla PP2) ${ }^{26}$. Em política social (PS) foram incluídos os projetos das categorias Saúde, Educação e Trabalho.

O objetivo da criação dessa variável foi o de visualizar a forma como os deputados federais vêm buscando ou não a implementação da doutrina da proteção integral em seus projetos, de acordo com a referência ao aspecto piramidal que esta doutrina possui. A inclusão da categoria PP2 na política penal, ao lado da categoria PP1, deve-se à adoção de uma perspectiva que compreende as propostas de aumento do prazo de internação como medidas repressivas, com finalidade punitiva. Trata-se de uma leitura mais descritiva do que prescritiva. Estáse aqui utilizando a perspectiva de como as medidas socioeducativas são tratadas hoje pelas mais diversas instâncias da sociedade, em especial, o Legislativo. Além disso, a categoria criminalização não é pensada como proteção, mas sim como

26 De acordo com o marco teórico do trabalho, não é possível falar em criminalidade e criminoso como dados ontológicos, mas sim como resultados de processos de criminalização. Da mesma maneira, na linguagem do Estatuto, o ato infracional somente existe dentro de processos de infracionalização, através da elaboração de normas que reprimem o adolescente em conflito com a lei - infracionalização primária e, em seguida, através da atribuição do status de infrator pelo processo de infracionalização secundária. Sem ingressar na polêmica envolvendo os defensores do direito penal juvenil e dos defensores da autonomia do direito da criança e do adolescente, não há como negar que, descritivamente falando, a medida socioeducativa de internação é encarada preponderantemente como sanção no discurso público hegemônico e, quando não é assim, é vista segundo a ótica menorista, como um bem ao adolescente, com a tendência a sua ilimitação pelos direitos. SANTOS, Juarez Cirino. O adolescente infrator e os direitos humanos. Para uma análise da referida polêmica, cf. BUDÓ, Marília De Nardin. Mídias e discursos do poder: a legitimação discursiva do encarceramento da juventude pobre no Brasil. 
repressão, tendo em vista o marco teórico deste trabalho, que reconhece na criminalização uma forma de reprodução social das desigualdades ${ }^{27}$ e a ausência de função de tutela de bens jurídicos pelo direito penal, por vários motivos, mas, especialmente, porque nada ele efetivamente protege ao intervir no conflito depois de o dano ter ocorrido, e por não ter o objetivo de reparação, mas sim de exclusão social seletiva dos culpados $^{28}$.

Após essas justificações sobre as escolhas realizadas para a análise qualiquantitativa dos PLs, passa-se, a seguir, aos resultados.

\section{A PUNIÇÃO É A RESPOSTA: OS PROJETOS DE LEI SOBRE A CRIANÇA E O ADOLESCENTE}

De 01 de janeiro de 2003 a 31 de dezembro de 2012 foram 314 projetos de lei apresentados por deputados na Câmara dos Deputados buscando alterar o ECA. O Gráfico 1 apresenta a distribuição desses projetos conforme o ano da proposição.

Gráfico 1 - Frequência de Projetos de Lei De Alteração do ECA (2003-2012)

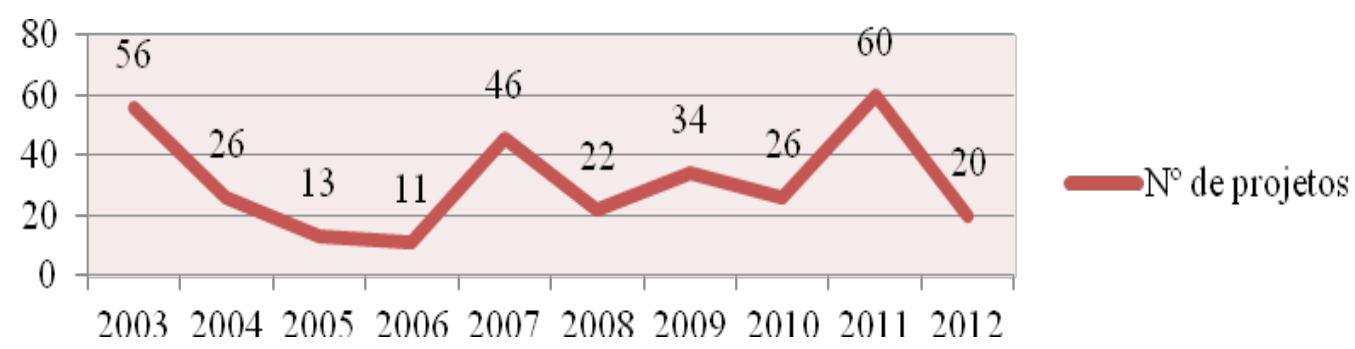

Fonte: Elaboração própria com base em dados coletados no sítio da Câmara dos Deputados (www.camara.leg.br).

Os três picos que aparecem são os anos de 2003, 2007 e 2011, os quais coincidem com os primeiros anos da 52a $5^{a} 3^{a}$ e $54^{a}$ legislaturas. Os anos eleitorais, mesmo aqueles municipais, constituem os de menor número de proposições.

27 BARATTA, Alessandro. Criminologia crítica e crítica do direito penal.

28 ZAFFARONI, E. Raúl; BATISTA, Nilo; SLOKAR, Alejandro; ALAGIA, Alejandro. Direito penal brasileiro. v. I. 2. ed. Rio de Janeiro: Revan, 2003. 
Do total de projetos de lei analisados, o maior número foi o contido na categoria criminalização (65 PLs) e, em segundo lugar, na categoria infracionalização (44 PLs). Em terceiro lugar, vêm as categorias conselhos tutelares (39 PLs) e, a seguir, prevenção especial (34 PLs).

Reunidos, os projetos das categorias PP1 e PP2, correspondentes a políticas repressivas, formamotítulopolíticapenal, davariável política pública, correspondendo a mais de um terço de todos os projetos propostos. Quando comparados apenas os projetos de política penal e política social, resulta que aqueles correspondem a $80,3 \%$, contra $19,7 \%$ destes, conforme mostra a Tabela 1.

Tabela 1- Política Penal X Política Social

\begin{tabular}{|c|c|c|c|c|c|}
\hline & & FREQUÊNCIA & PERCENTUAL & PERCENTUAL VÁLIDO & PERCENTUAL CUMULATIVO \\
\hline & Política penal & 110 & 35 & 80,3 & 80,3 \\
\hline \multirow[t]{2}{*}{ Válidos } & $\overline{\text { Política social }}$ & 27 & 8,6 & 19,7 & 100,0 \\
\hline & Total & 137 & 43,6 & 100,0 & \\
\hline Missing & Outros & 177 & 56,4 & & \\
\hline Total & & 314 & 100,0 & & \\
\hline
\end{tabular}

Fonte: Elaboração própria com base em dados coletados no sítio da Câmara dos Deputados (www.camara.leg.br).

Esse dado vem confirmar o que se tem observado ao longo dos últimos vinte anos na maior parte do mundo ocidental, não apenas no Brasil: a predominância da adoção de posturas estatais repressivas em detrimento de posturas voltadas ao bem-estar social. Trata-se de uma realidade trazida simultaneamente à perda do poder econômico por parte do Estado a partir dos conselhos dos ideólogos neoliberais. Estado mínimo não é significado de Estado ausente nessa lógica, mas de um mero sinal invertido, de um Estado policial: mínimo na esfera social; máximo na esfera penal ${ }^{29}$.

29 WACQUANT, Loïc. Punir os pobres: A nova gestão da miséria nos Estados Unidos. 2. ed. Rio de Janeiro: Revan/ICC, 2003. 
A insegurança dessa fórmula resultante - a respeito do emprego, da aposentadoria, da saúde, da educação - acaba sendo convertida em insegurança pública, em medos concretos ligados ao crime e à violência individual. Como acentua Bauman, "reformular as irremediáveis preocupações com a segurança individual, plasmando-as em ânsia de combate ao crime efetivo ou potencial e, assim, de defesa da segurança pública é um eficiente estratagema político que pode dar belos frutos eleitorais"30.

$\mathrm{Na}$ área da infância e da adolescência essa regra parece se confirmar, a despeito de o ECA possuir, desde a sua elaboração, um forte viés social. Se, por um lado, a Constituição Federal de 1988 adotou a doutrina da proteção integral, condicionando o surgimento do ECA dois anos após à mesma vertente ideológica, as propostas tendentes a alterar essa avançada legislação caminham no sentido contrário. A preponderância dessas políticas repressivas em detrimento das sociais, somada às taxas de homicídios de adolescentes e jovens, inclusive pela polícia, leva à conclusão trazida por Moraes: o que efetivamente têm sido as políticas públicas disponíveis e aplicadas a esta população são repressão, prisão e extermínio. Tudo resulta, então, em uma policialização da sociedade e dos conflitos sociais ${ }^{31}$.

Os dados anteriormente apresentados demonstram que as propostas do Legislativo na área da criança e do adolescente não se subtraem a essa lógica. Por detrás de um forte discurso protetivo, figura uma série de práticas punitivas, somadas à ideologia menorista. Além disso, a ideia de que por meio da punição rigorosa de criminosos, que se aproveitam da ingenuidade infantil para praticar as mais diversas condutas danosas, estar-se-ia protegendo as crianças e adolescentes, demonstra que proteção e repressão acabam figurando do mesmo lado da moeda: a da política penal. A partir dessa realidade, Baratta observa que:

O sistema dos direitos das crianças e dos adolescentes foi, até o momento, esmagado por duas emergências: a emergência risco-abandono e a emergência criminal. Por conseguinte, e contrariamente ao proposto pela Constituição e pelo Estatuto, na ótica institucional e na opinião pública,

30 BAUMAN, Zygmunt. Em busca da política. Rio de Janeiro: Jorge Zahar, 2000. p. 59.

31 MORAES, Pedro Rodolfo Bodê de. Juventude, medo e violência. Ciclo de conferências direito e psicanálise: novos e invisíveis laços sociais. 2005. Disponível em: http://www.ipardes.gov.br/pdf/cursos_eventos/ governanca_2006/gover_2006_01_juventude_medo_pedro_bode.pdf. Acesso em: 22 ago. 2012. 
prevaleceram as políticas públicas de resposta contingencial a essas urgências, e não as políticas públicas básicas, que deveriam representar a forma estrutural e preventiva de intervenção nas condições sociais e nos serviços fundamentais (escola, saúde, ambiente, trabalho, relações de propriedade), das quais dependem as emergências ${ }^{32}$.

Na busca pelos fatores que agem no sentido de aumentar o domínio do sistema penal (sem justificativa racional) no parlamento, Hulsman explica que, dentre eles, está o fato de este ser o único que não traz a necessidade de o legislador indicar de onde os recursos orçamentários serão extraídos para a efetivação da proposta. Como consequência, em períodos de dificuldades econômicas, a pressão por criminalização se torna mais forte ${ }^{33}$.

A relação entre a adoção de posturas punitivas e o partido político dos parlamentares foi também objeto de análise. O Gráfico 4 apresenta os resultados desse cruzamento.

Gráfico 4- Política X Partidos Políticos

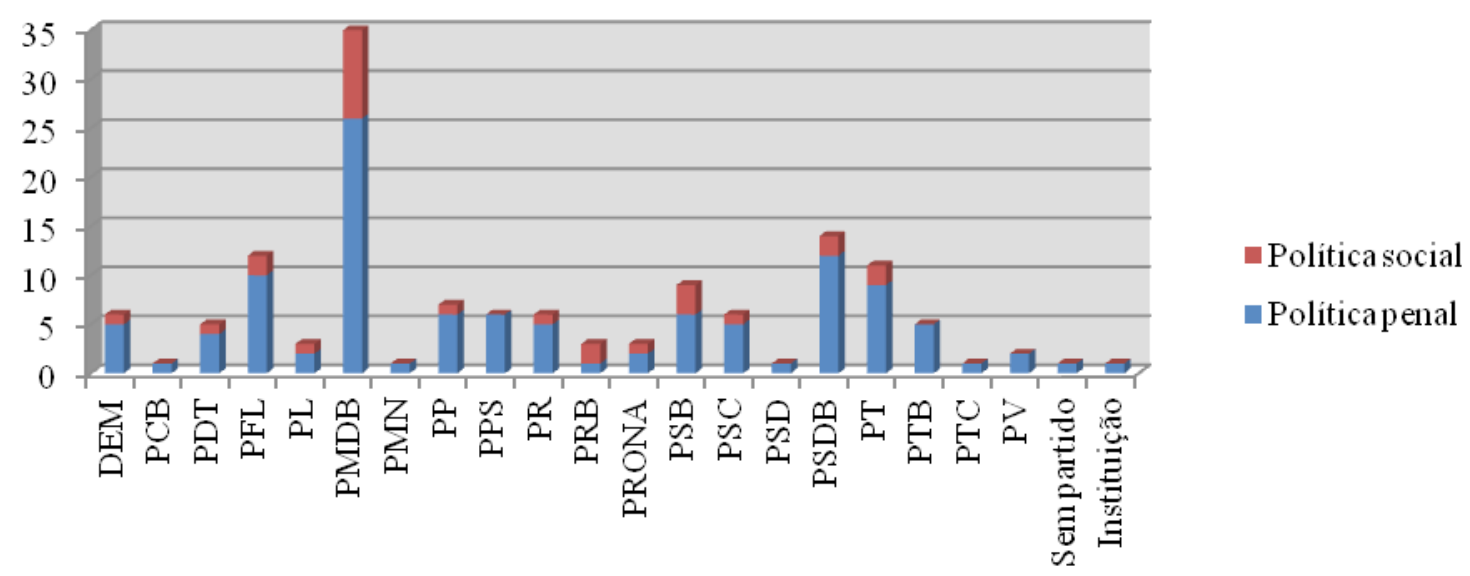

Fonte: Elaboração própria com base em dados coletados no sítio da Câmara dos Deputados (www.camara.leg.br).

Como se pode ver, há a predominância de propostas legislativas em matéria de política penal em relação à política social em quase todos os partidos. A opção por propor políticas penais, quando o tema é o número de proposições

32 BARATTA, Alessandro. Prefácio. In: BATISTA, Vera Malaguti. Difíceis ganhos fáceis: Drogas e juventude pobre no Rio de Janeiro. Rio de Janeiro: Revan, 2003. p. 30.

33 HULSMAN, Louk H. Descriminalização, Revista de Direito Penal, n. 9/10, Rio de Janeiro: Revista dos Tribunais, 1973, p. 7-26. 
buscando alterar o Estatuto da Criança e do Adolescente independe da orientação ideológica dos partidos tradicionalmente considerados de direita e esquerda ${ }^{34}$.

Observa-se, por exemplo, um grande número de propostas na área social por parte do $\mathrm{PMDB}$, considerado de centro, e do PSB, o qual se encontraria na centro-esquerda. Mas os partidos de esquerda, como o PT, o apresentam pouca produção legislativa nessa área.

Essa análise sobre o fortalecimento da esfera penal do Estado costuma vir acompanhada de um importante debate também ligado ao momento político que se vive na atualidade: o esvaziamento da distinção entre esquerda e direita. Desde o surgimento dos estudos sobre o populismo punitivo no início da década de 1990, percebe-se certa miscelânea entre os partidos políticos das mais diversas histórias e tradições na adoção de uma postura predominantemente repressiva.

Apesar de a presidência da República, em todo o período analisado, ter sido ocupado por um partido de esquerda, o Partido dos Trabalhadores, e algumas políticas sociais terem sido privilegiadas, como aquelas de distribuição de renda, também foi neste período que o maior número de políticas penais propostas pelo Executivo foram aprovadas no Parlamento. Em estudo sobre a legislação penal produzida entre 1989 e 2006, Campos mostra que, das quarenta leis penais aprovadas, quinze foram de iniciativa de partidos de esquerda, onze das quais penalizadoras ${ }^{35}$. A característica principal dessa legislação é a de se

34 Não obstante o frequente questionamento a respeito da existência de importantes diferenças ideológicas entre os partidos políticos no Brasil, sobretudo na última década, há estudos realizados no campo da ciência política que, baseados nos manifestos dos partidos, na opinião dos experts, dos eleitores ou ainda em entrevistas com os políticos, que demonstram a permanência dessa diferenciação. Tarouco e Madeira explicam que, apesar de os mecanismos europeus de avaliação da orientação ideológica de partidos políticos não corresponderem a todas as realidades, como a brasileira, em razão de questões históricas e culturais, vários autores vêm buscando realizar tal análise a partir de diferentes métodos. A caracterização realizada pelos autores, contudo, não leva em consideração o comportamento legislativo, ou seja, o comportamento estratégico desenvolvido pelos parlamentares em razão das circunstâncias políticas momentâneas e as coalizões realizadas independentemente de posições ideológicas no parlamento. Outra questão importante é que essa análise não comporta as especificidades regionais de cada partido, mas apenas o que eles declaram ser de suas prioridades mais gerais. A partir desse estudo, dentre outros, optou-se por considerar as orientações ideológicas dos partidos da seguinte maneira: PSOL, PT e PC do B como esquerda; PDT, PCB/PPS, PSB, PV como centro-esquerda; PMDB e PHS como centro; PMN, PSC, PTB, PAN e PSDB como centro-direita; PDS/PPR/PPB/PP, PFL/DEM, PRONA, PSD, PTC, PR, PL, PRTB, PRB como direita. TAROUCO, Gabriela da Silva; MADEIRA, Rafael Machado.Left and right in the Brazilian party system.XI Congress of the Brazilian Studies Association. 6-8 September 2012. University of Illinois at Urbana-Champaign. Disponível em: http://www.brasa.org/documents/brasa_xi/Gabriela-Tarouco-Rafael-Madeira.pdf. Acesso em: 18 jan. 2013.

35 CAMPOS, Marcelo da Silveira. Crime e Congresso Nacional: uma análise da política criminal aprovada de 1989 a 2006. p. 148. 
voltar às demandas dos movimentos sociais, como os movimentos feministas, os movimentos de defesa da criança e do adolescente, os movimentos contra a discriminação racial, etc., desconsiderando o fato de o próprio sistema penal ser estruturalmente classista, patriarcal e racista ${ }^{36}$.

\section{OS DOIS SENTIDOS DA POLÍTICA PENAL EM MATÉRIA DE CRIANÇA E ADOLESCENTE}

Do total de projetos de lei propostos na categoria política penal, 58,41\% foram incluídos na categoria PP1; e 41,59\%, na categoria PP2, o que demonstra certo equilíbrio, com a predominância, contudo, da primeira. O Gráfico 6 apresenta a distribuição desses projetos de lei ao longo desses dez anos:

Gráfico 6- Política Penal X Ano

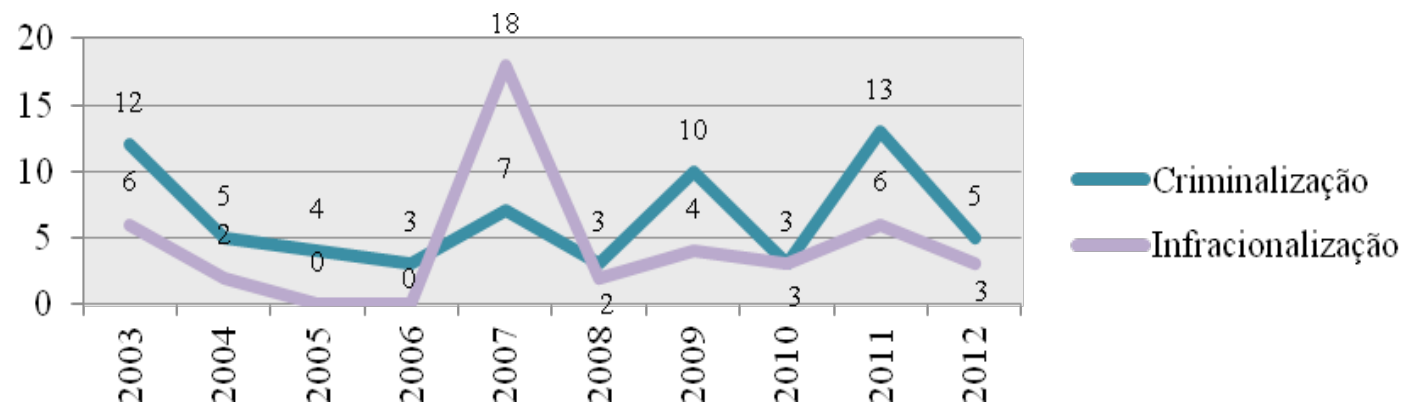

Fonte: Elaboração própria com base em dados coletados no sítio da Câmara dos Deputados (www.camara.leg.br).

Na distribuição ao longo desse tempo há certa correspondência entre os anos em que houve maior número de PLs apresentados em uma e em outra categoria. Apesar de quantidades e distribuição diferentes, é possível verificar que tanto os projetos de lei de criminalização de condutas quanto aqueles sobre o recrudescimento da medida socioeducativa de internação atingem os seus maiores números nos anos de 2003, 2007, 2009 e 2011. No caso da categoria PP1, ressaltam-se os anos de 2003, 2009 e 2011. No caso da categoria PP2, nota-se que há um pico isolado no ano de 2007, correspondendo a um período em que houve grande cobertura midiática e comoção social em relação ao ato infracional ${ }^{37}$.

37 No dia 7 de fevereiro de 2007, um menino de seis anos foi morto em um assalto, arrastado pelo cinto de segurança do carro da mãe quando ele estava sendo roubado por um grupo de quatro adultos e um 
Apesar de haver certa consonância teórica, como visto anteriormente a respeito da priorização de posturas punitivistas em todo o espectro político da atualidade, independentemente do perfil ideológico, um contraste, porém, costuma ser indicado pelos autores: a direita estaria preocupada com a criminalização da miséria (direita criminológica), enquanto a esquerda lançaria mão da repressão contra o crime de colarinho branco, além das demandas punitivas dos movimentos sociais (esquerda punitiva) ${ }^{38}$.

Para investigar esse possível traço distintivo, partiu-se para um novo cruzamento de dados, agora separando as categorias PP1 e PP2, bem como agrupando os partidos conforme o seu pertencimento ao perfil ideológico. O Gráfico 7 aponta os resultados do cruzamento conforme o partido político.

\section{Gráfico 7 - Política Penal X Partido}

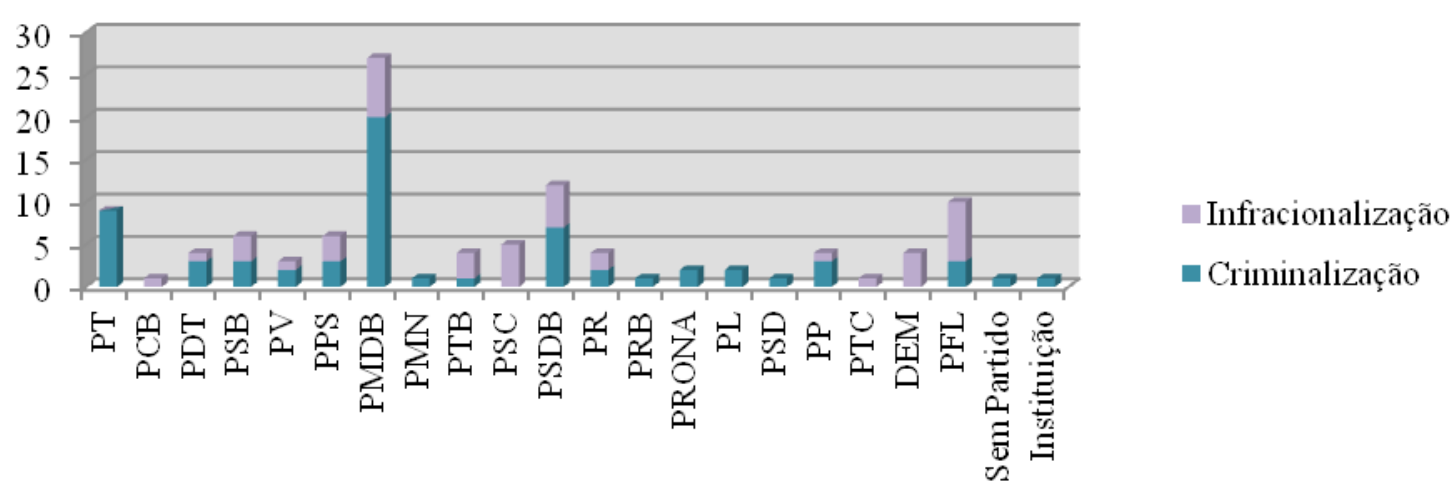

Fonte: Elaboração própria com base em dados coletados no sítio da Câmara dos Deputados (www.camara.leg.br).

adolescente no Rio de Janeiro. O caso João Hélio, como ficou conhecido, teve como principal foco o adolescente e seu irmão, de 23 anos, que estava cumprindo pena em regime semiaberto. Ambas as situações reacenderam demandas sociais por punições mais severas. Os principais debates foram sobre a redução da maioridade penal, a elevação do prazo de internação e a criação de obstáculos à progressão de regime dos adultos encarcerados. BUDÓ, Marília De Nardin. Mídias e discursos do poder: a legitimação discursiva do encarceramento da juventude pobre no Brasil.

38 A respeito da bifurcação do sistema penal globalizado, cf. ANDRADE, Vera Regina Pereira de. Movimentos contemporâneos de controle do crime. Violência e controle social na contemporaneidade. Anais do III Ciclo de Estudos e Debates sobre Violência e Controle Social. p. 143-148. Porto Alegre: PUC-RS, 2008. Especificamente sobre os movimentos da direita criminológica e esquerda punitiva, cf., respectivamente, PEGORARO, Juan. Derecha criminológica, neoliberalismo y política penal. Delito y sociedad: Revista de Ciencias Sociales, Buenos Aires, año 10, n. 15/16, p. 141-160, 2001 e KARAM, Maria Lúcia. A esquerda punitiva, Discursos sediciosos: crime, direito e sociedade, ano 1, número 1 , $1^{\circ}$ semestre de 1996., p. 79-92. 
Da representação gráfica extrai-se que, mesmo apelando para a repressão penal, os deputados de partidos tradicionalmente classificados como de esquerda não costumam apresentar projetos de lei visando à infracionalização (PP2), mas claramente optam pela criminalização de condutas praticadas contra crianças e adolescentes (PP1). Por outro lado, os partidos que tiveram um número de projetos de lei apresentados na categoria PP2 superior à PP1 foram dois partidos de direita e um de centro-direita: respectivamente, Partido da Frente Liberal/Democratas $(\mathrm{PFL} / \mathrm{DEM})^{39}$, Partido da República (PR) ${ }^{40}$ e Partido Trabalhista Brasileiro (PTB). Da mesma maneira, os partidos que tiveram apenas PLs propostos na categoria PP2 são predominantemente de direita, o Partido Trabalhista Cristão (PTC) e o Partido Social Cristão (PSC), com exceção do Partido Comunista do Brasil (PCdoB), considerado de esquerda.

O Partido Progressista (PP), tradicionalmente classificado como de direita, apresentou o mesmo número de projetos nas duas categorias. Assim também o Partido Popular Socialista (PPS), o Partido Socialista Brasileiro (PSB) e o Partido da Social Democracia Brasileira (PSDB). O Partido Democrático Trabalhista (PDT), o Partido do Movimento Democrático Brasileiro (PMDB) e o Partido Verde (PV) tiveram um número de propostas na categoria PP1 superior à categoria PP2. Por fim, alguns partidos propuseram apenas na categoria PP1: Partido Liberal (PL), Partido da Mobilização Nacional (PMN), Partido Republicano Brasileiro (PRB), Partido da Reedificação da Ordem Nacional (PRONA) e Partido dos Trabalhadores (PT).

Analisando partido por partido, verifica-se que há PLs propostos em ambas as categorias na maior parte deles, não se apresentando, aparentemente, grandes divergências conforme o perfil ideológico, com exceção da oposição entre o PFL/DEM e o PT. Contudo, quando agrupados, o resultado do cruzamento parece indicar um contraste entre as categorias PP1 e PP2 conforme a orientação ideológica. É o que demonstra o Gráfico 8.

39 O Partido da Frente Liberal foi fundado em 1985 a partir de uma cisão no Partido Democrático Social (PDS), hoje Partido Progressista (PP), no período da abertura política. Em 2007, o partido foi refundado e mudou de nome para Democratas (DEM).

40 O Partido da República foi criado em 2006, sendo o produto da fusão entre o Partido Liberal (PL) e o Partido da Reedificação da Ordem Nacional (PRONA). 
Gráfico 8 - Política Penal X Perfil Ideológico

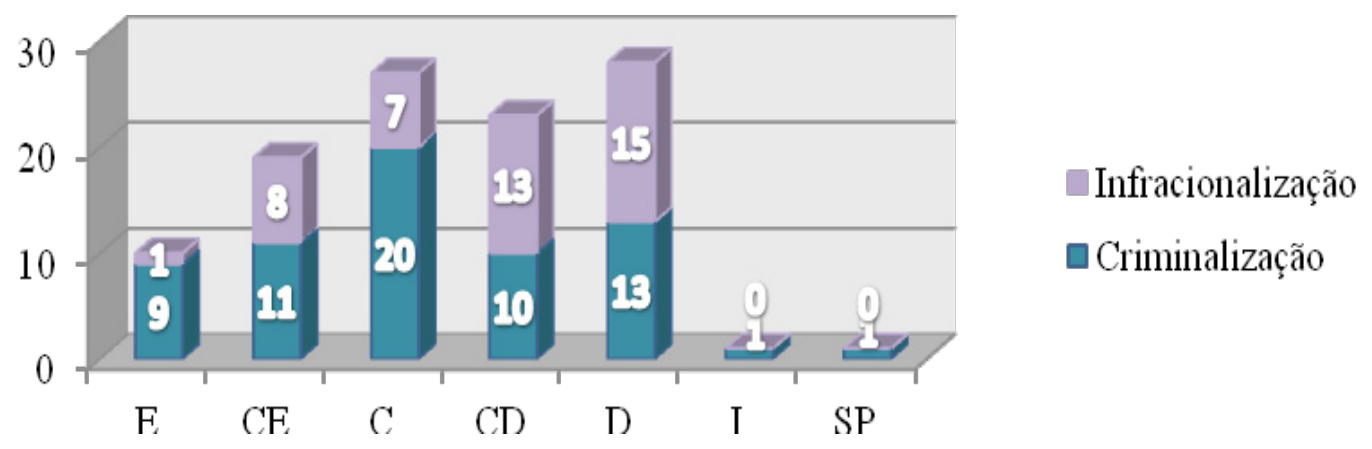

Fonte: Elaboração própria com base em dados coletados no sítio da Câmara dos Deputados (www.camara.leg.br)

Em geral, é possível afirmar que os partidos de esquerda costumam se filiar fortemente à doutrina da proteção integral e, portanto, à manutenção de limites rígidos quanto a temas como a redução da maioridade penal e o aumento do prazo de internação. Defender esses limites significa buscar proteger a criança e o adolescente do arbítrio antes dispensado em seu tratamento quando da prática do ato infracional. Por outro lado, a criminalização de condutas da forma como realizada nesses PLs vem acompanhada de um lamento quanto à vitimização de crianças, e a necessidade de punição daqueles que as vitimizam ou as põem em perigo. Postar-se ao lado da criminalização nesse caso significa, aos olhos do senso comum, apresentar soluções contra os algozes da infância. Trata-se de uma demanda de proteção, aliada à demanda de punição.

Assim, a predominância dos projetos de política penal na categoria PP1 nos partidos de esquerda e de centro-esquerda é resultado da representação da criança e do adolescente que se pauta na ideia de vulnerabilidade, tanto quando pratica ato infracional quanto quando é vítima de um crime praticado por um adulto ${ }^{41}$. Em razão disso, a opção pela criminalização se dá no polo que se entende ser o mais forte da relação: no caso da criança ou adolescente vítima, a criminalização será do autor do fato; no caso do adolescente autor do fato, não se pode implicar mera criminalização em razão da sua situação, quer seja ligada ao caráter de pessoa em desenvolvimento, quer seja relacionada à condição social da qual provém. Essa

41 BUDÓ, Marília De Nardin. Mídias e discursos do poder: a legitimação discursiva do encarceramento da juventude pobre no Brasil. 
opção acaba canalizando o discurso para uma compreensão mais complexa sobre o ato infracional, fugindo da mera perspectiva binária bandido versus vítima, apesar de isso acabar ocorrendo quando se trata da categoria PP1.

No caso das opções tomadas pelos partidos de direita e centro direita também se percebe uma coerência, não quanto à representação do adolescente, que parece ser visto como vítima no caso da categoria PP1, mas como "bandido", no caso da categoria PP2, porém, da lógica da punição adotada em ambos os casos. Trata-se de uma percepção que enquadra dois tipos de problemas no mesmo tipo de investigação causal e na mesma solução possível: de um lado, a criança indefesa está à mercê de adultos criminosos, cuja causa são as penas brandas do ECA e a solução está no recrudescimento da criminalização destes; de outro lado, a sociedade amedrontada está à mercê de adolescentes irresponsáveis, descomprometidos e criminosos devido à leniência do ECA, ao não prever uma medida mais séria ao adolescente que pratica atos infracionais graves ${ }^{42}$. A solução, novamente, está no recrudescimento da resposta repressiva do Estado, agora contra os adolescentes.

\section{POPULISMO PENAL E AMBIGUIDADE DA POSTURA PUNITIVISTA}

A maior parte dos projetos de lei buscando incrementar a punição de adolescentes autores de ato infracional foi proposta em um período de desenvolvimento de um pânico moral ${ }^{43}$, por possuir as características específicas para que isso ocorresse: um crime grave - latrocínio; cuja vítima cabe no estereótipo; cujos infratores também são vistos como inimigos da sociedade ${ }^{44}$. 0 papel da mídia na divulgação do caso João Hélio é fundamental na compreensão da dimensão que o ato infracional tomou naquele período, sobretudo no que tange à ênfase na participação do adolescente.

42 Nos limites deste artigo não foi possível incluir a análise qualitativa de discurso das justificativas dos projetos de lei, bem como a lista dos projetos de lei analisados. Para acessá-las, cf. BUDÓ, Marília De Nardin. Mídias e discursos do poder: a legitimação discursiva do encarceramento da juventude pobre no Brasil.

43 COHEN, Stanley. Folk devils and moral panics. 3. ed. London and New York: Routledge, 2002.

44 BUDÓ, Marília de Nardin. Mídia e controle social: da construção da criminalidade dos movimentos sociais à reprodução da violência estrutural. Rio de Janeiro: Revan, 2013. 
Os estudos produzidos por autores da Criminologia acerca da relação entre políticas penais e mídia nos últimos anos costumam estabelecer a crítica de que a produção legislativa nessa matéria é marcada pelo imediatismo, no afã de apresentar respostas pontuais à opinião pública ${ }^{45}$. Trata-se, em verdade, de uma situação identificada em diferentes países, do Reino Unido à Argentina, do Brasil aos Estados Unidos. Tanto é que autores provenientes das mais diversas partes do mundo ocidental vêm publicando, em especial a partir da década de 1990, a respeito dessas constatações. Na Inglaterra, as respostas legislativas, em um contexto neoliberal, que provocaram sério aumento no encarceramento, foram discutidas por Anthony Bottoms sob o conceito de populist punitiveness ${ }^{46}$. Dois anos depois, o termo penal populism foi criado e então circulou o mundo, sendo usado para descrever o uso do direito penal para estabelecer uma relação de confiança da opinião pública nos governantes a partir de uma ilusão de segurança.

Os meios de comunicação de massa vêm desempenhando papel fundamental nesse processo, pois, do entretenimento ao jornalismo, garantem excessiva prioridade a uma determinada representação do crime e privilegiando os espaços de repercussão de discursos punitivistas ${ }^{47}$.

Esses discursos, impregnados de referências aos sentimentos do que pensa "a nossa gente", "o cidadão de bem", e voltados exclusivamente a um auditório de pessoas sedentas por punição, vêm exigindo, como nota Sozzo, a emergência e a sobreposição de um novo tipo de especialidade na construção de estratégias de controle do crime: "o dos 'especialistas' em opinião pública transformados em 'consultores' e 'assessores' dos atores políticos"48.

A receptividade do discurso punitivista na sociedade pode ser verificada na audiência de programas de televisão que acompanham prisões, levando a uma 45 ZAFFARONI, Eugenio Raúl. A palavra dos mortos: Conferências de criminologia cautelar. São Paulo: Saraiva, 2012. BARATA VILLAR, Francesc. La construcción mediática de la culpabilidad: Cuando las noticias interfieren en las políticas criminales y aumentan ansias punitivas. In: BOZZA, Fábio; ZILIO, Jacson. Estudos críticos sobre o sistema penal. Curitiba: LedZe, 2012. p. 717-746. PERES-NETO, Luis. Prensa, política criminal y opinión pública: el populismo punitivo en España, Tesis doctoral, Barcelona: Universidad Autónoma de Barcelona, 2010.

46 PRATT, John. Penal populism. New York: Routledge, 2007.

47 SILVERMAN, Jon. Crime, Policy and the Media: the Shaping of Criminal Justice, 1989-2010. London: Routledge, 2012.

48 SOZZO, Máximo. Populismo punitivo, proyecto normalizador y "prisión-depósito" en Argentina. Sistema Penal \& Violência, Porto Alegre, v. 1, n.1, p. 33-65, julho-dezembro, 2009. p. 42. 
transformação da vida em um reality show, no qual, assim como na ficção, existem mocinhos e bandidos, aqueles estereotipados como "homens de bem", estes caracterizados como monstros anormais que representam uma ameaça para a sociedade. É a partir dessa receptividade, medida também por variadas e frequentes pesquisas de opinião sobre temas como pena de morte, progressão de regime, redução da maioridade penal, entre outros, que certa parte do discurso político busca afirmar o caráter democrático da adoção de posturas punitivistas ${ }^{49}$.

No contexto norte-americano, Katherine Beckett nota que várias são as maneiras pelas quais pode a cobertura midiática influenciar a política ${ }^{50}$ : a) a influência pode ser direta, independente do impacto da opinião pública, apenas em função do aumento das notícias sobre determinado problema social; o interesse da mídia por determinados assuntos pode ser usado pelos políticos como meio de garantir sua exposição nos meios de comunicação. Assim, independentemente dos potenciais efeitos na opinião pública, a cobertura midiática pode influenciar o processo de policy-making nos níveis local e federal. b) Por mais que não se possa simplesmente afirmar que o discurso midiático causa mudanças na opinião pública, é induvidoso que ela é um componente crucial do contexto no qual as opiniões políticas são formadas.

Tais medidas são instituídas para simbolizarem ações expressivas, catárticas, de maneira a censurar o crime e confortar o público. Sua capacidade de controlar o crime futuro, conquanto ruidosamente decantada, é frequentemente duvidosa e, em todo caso, menos importante do que sua habilidade imediata de representar o sentimento público, de proporcionar respostas instantâneas, de funcionar como medida retaliadora cuja virtude é sua própria existência. Estas medidas são tipicamente aprovadas no calor da indignação popular em face de crimes violentos marcantes, que envolvem o perturbador e arquetípico confronto entre um criminoso perigoso deficientemente controlado e uma vítima inocente, indefesa, da classe média ${ }^{51}$.

49 BUDÓ, Marília de Nardin. Opinião pública, política e hegemonia: para além do populismo penal. In: OLIVEIRA, Rafael Santos de; SILVA, Rosane Leal da. Direito e novas mídias. Curitiba: Íthala, 2015. p. 81-100.

50 BECKETT, Katherine. Making crime pay. Oxford/New York: Oxford University Press, 1997. p. 78.

51 GARLAND, David. A cultura do controle. Rio de Janeiro: Revan/ICC, 2008. p.282. 
No Brasil, apesar de as proporções serem outras, o fenômeno cada vez se mostra mais palpável. Não são poucos os políticos que se elegeram com pautas de dureza contra o crime. Porém a orientação do Executivo nos governos do PT, no que tange ao ato infracional, é profundamente contrária à lógica punitivista, trabalhando com a prevenção por meio de programas de inclusão social ${ }^{52}$. O problema encontrado é o de que, a despeito de essa orientação ser mais condizente com o ECA do que aquelas que buscam apenas excluir socialmente os autores de ato infracional, ela ainda se posta no binômio abandono-infração, típica do menorismo. Daí que os adolescentes facilmente transitem, na imagem do governo, de vítimas a criminosos, de adolescentes em perigo a adolescentes perigosos. O resultado disso, contudo, não implica necessariamente a sua maior criminalização, mas sim na legitimação de políticas baseadas em um determinismo que vincula pobreza e criminalidade.

Outra questão interessante é o fato de que os partidos de esquerda, especialmente o PT, não se constrangem em propor políticas penais graves quando se trata da criminalização de adultos que vitimizam crianças. Daí que, ao contrário do que se esperaria de mais de dez anos de governos de esquerda, foram muitas as reformas no ECA para adicionar novos tipos penais e incrementar penas ${ }^{53}$, além de outras mudanças nos códigos penal, processual penal e na lei de execução penal as quais buscaram aumentar o encarceramento.

52 Essa orientação do PT pode ser visualizada no voto em separado na Comissão de Segurança Pública e Combate ao Crime Organizado (CSPCCO) elaborado pelo Deputado Paulo Teixeira aos PLs 7008/2010 e 7398/2010 no dia 29 de junho de 2010. O autor se posiciona pela rejeição dos projetos, ambos destinados a ampliar o prazo máximo de internação, rebatendo sua argumentação pontualmente e observando, principalmente, a sua desconformidade com os princípios da brevidade, excepcionalidade e respeito à condição peculiar de pessoa em desenvolvimento. BRASIL. Câmara dos Deputados. Comissão de Segurança Pública e Combate ao Crime Organizado. Voto em separado aos PLs 7008/2010 e 7398/2010. Deputado Paulo Teixeira. 29 jun. 2010. Disponível em: http://www.camara.gov. br/proposicoesWeb/prop_mostrarintegra?codteor=784908\&filename=VTS+1+CSPCCO+\%3D\%3E+PL+7008/2010. Acesso em: 22 out. 2012. Tal posicionamento aparece ainda nas manifestações das deputadas do PT Dalva Figueiredo e Benedita da Silva também na CSPCCO, respectivamente, na elaboração do voto em separado no âmbito do PL 345/2011, em 5 de maio de 2011, e no parecer da relatora no âmbito do PL 347/2011, em 21 de junho do mesmo ano, ambos projetos incluídos na categoria PP2. BRASIL. Câmara dos Deputados. Comissão de Segurança Pública e Combate ao Crime Organizado. Parecer ao PL 347/2011e apensado PL 1052/2011. Relatora Benedita da Silva. 21 de junho de 2011. Disponível em: <http://www.camara.gov.br/proposicoesWeb/prop_mostrarintegra?codteor=891 428\&filename=Parecer-CSPCCO-21-06-2011>. Acesso em: 22 ago. 2012. BRASIL. Câmara dos Deputados. Comissão de Segurança Pública e Combate ao Crime Organizado. Voto em separado ao PL 345/2011. Deputada Dalva Figueiredo. 05 mai. 2011. Disponível em: http://www.camara.gov.br/proposicoesWeb/prop_mostrarintegra?codteor= 867542\&filename=VTS+3+CSPCCO+\%3D\%3E+PL+345/2011. Acesso em: 22 out. 2012.

53 A Lei $n^{\circ} 10.764$, de 12.11.2003 aumentou as penas de quatro tipos penais; já a Lei $n^{\circ} 11.829$, de 2008 , além de aumentar penas, acrescentou os artigos 241-A, 241-B, 241-C, 241-D e 241-E, relacionados à pornografia infantil. Esta última lei, de iniciativa do senado, foi o resultado da CPI da Pornografia infantil e tramitou durante apenas 5 meses até ser transformada em lei. 


\section{CONSIDERAÇÕES FINAIS}

O aumento do punitivismo no Brasil vem deixando importantes marcas em todas as áreas da produção legislativa. Punir se torna a solução para problemas ambientais, sociais, políticos, econômicos, etc. Não demorou para que essa face da política chegasse à esfera da criança e do adolescente. Se é possível afirmar que a representação social do adolescente no Brasil tem sido historicamente ambígua - de vítima em perigo a bandido perigoso -, então a conjuntura punitivista atual se adéqua a ela perfeitamente. De um lado, as propostas de alteração do Estatuto instrumentalizam o braço repressivo do Estado como forma de punir adultos que vulneram crianças inocentes; de outro lado, as propostas implicam o aumento da duração da privação da liberdade para punir os adolescentes considerados perigosos, que afrontam a paz de uma sociedade considerada consensual.

Este trabalho trouxe os resultados da pesquisa nos projetos de lei de alteração do Estatuto da Criança e do Adolescente nos últimos dez anos, com o objetivo de verificar qual é o sentido da mobilização política em torno do tema da criança e do adolescente no parlamento brasileiro. O número bastante superior das propostas envolvendo o aumento da repressão demonstrou que, ao contrário do previsto pela doutrina da proteção integral, os parlamentares brasileiros compartilham, em grande medida, a ideia de que as políticas penais podem ser ferramentas estratégicas para proteger e para punir.

De qualquer forma, é possível afirmar que, diante da movimentação parlamentar dirigida à utilização do braço repressor do Estado, nas duas direções antes apontadas a doutrina da proteção integral não está de fato sendo observada em sua estrutura piramidal. Tanto a representação social da criança e do adolescente permanece preponderantemente vinculada à doutrina da situação irregular, quanto o aumento do punitivismo vem auxiliando na identificação da repressão penal como a solução para todos os tipos de problemas no Brasil. 


\section{REFERÊNCIAS}

ANDRADE, Vera Regina Pereira de. Movimentos contemporâneos de controle do crime. Violência e controle social na contemporaneidade. Anais do III Ciclo de Estudos e Debates sobre Violência e Controle Social. p. 143-148. Porto Alegre: PUC-RS, 2008.

ANDRADE, Vera Regina Pereira de. Pelas mãos da criminologia. Rio de Janeiro: Revan/ICC, 2012.

BARATA VILLAR, Francesc. La construcción mediática de la culpabilidad: Cuando las noticias interfieren en las políticas criminales y aumentan ansias punitivas. In: BOZZA, Fábio; ZILIO, Jacson. Estudos críticos sobre o sistema penal. Curitiba: LedZe, 2012. p. 717-746.

BARATTA, Alessandro. Criminologia crítica e crítica do direito penal. 3. ed. Tradução de Juarez Cirino dos Santos. Rio de Janeiro: Revan/ICC, 2002.

BARATTA, Alessandro. Os direitos da criança e o futuro da democracia. In: Perspectivas do direito no início do século XXI. Boletim da Faculdade de Direito da Universidade de Coimbra, Studia Jurídica, n. 41, p. 61-91. Coimbra: Coimbra, 1999.

BARATTA, Alessandro. Prefácio. In: BATISTA, Vera Malaguti. Difíceis ganhos fáceis: Drogas e juventude pobre no Rio de Janeiro. Rio de Janeiro: Revan, 2003.

BAUMAN, Zygmunt. Em busca da política. Rio de Janeiro: Jorge Zahar, 2000.

BECKER, Howard. Outsiders: Studies in the sociology of deviance. New York: The Free Press, 1996.

BECKETT, Katherine. Making crime pay. Oxford/New York: Oxford University Press, 1997.

BRASIL. Câmara dos Deputados. Comissão de Segurança Pública e Combate ao Crime Organizado. Voto em separado aos PLs 7008/2010 e 7398/2010. Deputado Paulo Teixeira. 29 jun. 2010. Disponível em: http://www.camara.gov.br/proposicoesWeb/prop_mostrarinteg ra? codteor $=784908 \&$ filename $=V T S+1+C S P C C O+\% 3 D \% 3 E+P L+7008 / 2010$. Acesso em: 22 out. 2012.

BRASIL. Câmara dos Deputados. Comissão de Segurança Pública e Combate ao Crime Organizado. Parecer ao PL 347/2011e apensado PL 1052/2011. Relatora Benedita da Silva. 21 jun. 2011. Disponível em: <http://www.camara.gov.br/proposicoesWeb/prop_mostrarinte gra?codteor=891428\&filename=Parecer-CSPCCO-21-06-2011>. Acesso em: 22 ago. 2012. 
BRASIL. Câmara dos Deputados. Comissão de Segurança Pública e Combate ao Crime Organizado. Voto em separado ao PL 345/2011. Deputada Dalva Figueiredo. 05 mai. 2011. Disponível em: http://www.camara.gov.b r/proposicoesWeb/prop_mostrarintegra?codteor=8 67542\&filename=VTS+3+CSPCCO+\%3D\%3E+PL+345/2011. Acesso em: 22 out. 2012.

BRASIL. Lei n 8.069 de 13 de julho de 1990. Dispõe sobre o Estatuto da Criança e do Adolescente e dá outras providências. Disponível em: <http://www.planalto.gov.br/ccivil_03/ Leis /L8069.htm>. Acesso em: 20 jun. 2009.

BRASIL. Ministério da Justiça. Departamento penitenciário Nacional. População carcerária sintético:nov.2000. Disponívelem: <http://www.justica.gov.br/sua-seguranca/departamentopenitenciario-nacional/sistema-prisional/anexos-sistema-prisional/populacao-carcerariasintetico-2000.pdf>. Acesso em: 20 mar. 2013.

BRASIL. Secretaria de Direitos Humanos. Atendimento socioeducativo ao adolescente em conflito com a lei: Levantamento nacional 2011. Disponível em: <http://www.sdh.gov.br/ assuntos/criancas-e-adolescentes/pdf/Sinase Levantamento2011.pdf>. Acesso em: 25 jul. 2013.

BUDÓ, Marília de Nardin. Mídia e controle social: da construção da criminalidade dos movimentos sociais à reprodução da violência estrutural. Rio de Janeiro: Revan, 2013.

BUDÓ, Marília De Nardin. Mídias e discursos do poder: a legitimação discursiva do processo de encarceramento da juventude pobre no Brasil. Tese (Doutorado). Programa de Pósgraduação em Direito, Universidade Federal do Paraná, Curitiba, 2013. 542 f.

BUDÓ, Marília de Nardin. Opinião pública, política e hegemonia: para além do populismo penal. In: OLIVEIRA, Rafael Santos de; SILVA, Rosane Leal da. Direito e novas mídias. Curitiba: Íthala, 2015. p. 81-100.

BUDÓ, Marília de Nardin . Sobre bruxas e monstros pueris: do medo ao controle. In: Monica Ovinski de Camargo Cortina e Valter Cimolin. (Org.). Criminologia crítica. 1. ed.Curitiba: Multidéia, 2015, v. 2, p. 75-100.

CAMPOS, Marcelo da Silveira. Crime e Congresso Nacional: uma análise da política criminal aprovada de 1989 a 2006. São Paulo: IBCCRIM, 2010.

CIARALLO, Cynthia R. C. A.; ALMEIDA, Ângela Maria de O. Conflito entre práticas e leis: a adolescência no processo judicial. Fractal: Revista de Psicologia, v. 21, n. 3, p. 613-630, set./ dez. 2009. 
CILLERO BRUÑOL, Miguel. El interés superior del niño en el marco de la convención internacional sobre los derechos del niño. In: UNICEF. Justicia y derechos del niño, n. 9. Santiago, Chile: 2007. p. 125-142.

CNJ - CONSELHO NACIONAL DE JUSTIÇA. Departamento de Monitoramento e Fiscalização do Sistema Carcerário e do Sistema de Execução de Medidas Socioeducativas. Novo diagnóstico de pessoas presas no Brasil. Brasília: 2014. Disponível em: <http://www.cnj.jus.br/images/ imprensa/diagnostico_e_pessoas_presas_correcao.pdf>. Acesso em: 20 jul. 2014.

COHEN, Stanley. Folk devils and moral panics. 3. ed. London and New York: Routledge, 2002.

CORTÉS MORALES, Julio. A 100 años de la creación del primer Tribunal de Menores y 10 años de la Convención Internacional de los Derechos del Niño: el desafío pendiente. In: UNICEF. Justicia y derechos del niño, n. 9. Santiago, Chile: 2007. p. 143-158.

CNMP - CONSELHO NACIONAL DO MINISTÉRIO PÚBLICO. Relatório da Infância e Juventude - Resolução n 67/2011: Um olhar mais atento às unidades de internação e semiliberdade para adolescentes. Brasília: Conselho Nacional do Ministério Público, 2013. Disponível em: <http://www.cnmp.mp.br/portal/images/stories/Noticias/2013/Arquivos/Relat\%C3\%B3rio_ Interna\%C3\%A7\%C3\%A3o.PDF>. Acesso em: 20 abr. 2014.

CUSTÓDIO, André Viana. Teoria da proteção integral: pressuposto para compreensão do direito da criança e do adolescente. Revista do Direito, v. 29, p. 22-43, Santa Cruz do Sul, 2008.

FLAUZINA, Ana Lucia Pinheiro. Corpo negro caído no chão: o sistema penal e o projeto genocida do Estado brasileiro. Rio de Janeiro: Contraponto, 2008.

FRASSETO, Flávio Américo. Ato infracional, medida socioeducativa e processo: a nova jurisprudência do STJ. Discursos sediciosos: crime, direito e sociedade, ano 7, n. $12,2^{\circ}$ sem. 2002, p. 167-191.

GARCÍA MÉNDEZ, Emilio. Infancia, ley y democracia: una cuestión de justicia. In: UNICEF. Justicia y derechos del niño, n. 9. Santiago, Chile: 2007. p. 27-47.

GARCÍA MÉNDEZ, Emilio; COSTA, Antonio Carlos Gomes. Das necessidades aos direitos. São Paulo: Malheiros, 1994.

GARLAND, David. A cultura do controle. Rio de Janeiro: Revan/ICC, 2008. 
GOFFMAN, Erving. Manicômios, prisões e conventos. Tradução de Dante Moreira Leite. 7. ed. São Paulo: Perspectiva, 2001.

HULSMAN, Louk H. Descriminalização, Revista de Direito Penal, n. 9/10, Rio de Janeiro: Revista dos Tribunais, 1973, p. 7-26.

KARAM, Maria Lúcia. A esquerda punitiva, Discursos sediciosos: crime, direito e sociedade, ano 1 , número $1,1^{\circ}$ semestre de 1996., p. 79-92.

MAUGER, Gérard, Juventude: idades da vida e gerações.Dados [online], v. 56, n.1, 2013, pp. 169-183. Disponível em: <http://www.scielo.br/scielo.php?script= sci_arttext\&pid=S001152582013000100007\&lng=es\&nrm=iso >. Acesso em: 07 jan. 2014.

MIRAGLIA, Paula. Aprendendo a lição: uma etnografia das Varas Especiais da Infância e da Juventude. Novos Estudos, n. 72, jul. 2005. p. 79-98.

MORAES, Pedro Rodolfo Bodê de. Juventude, medo e violência. Ciclo de conferências direito e psicanálise: novos e invisíveis laços sociais. 2005. Disponível em: http://www.ipardes.gov. br/pdf/cursos_eventos/governanca_ 2006/gover_2006_01_juventude _medo_pedro_bode. pdf. Acesso em: 22 ago. 2012.

PEGORARO, Juan. Derecha criminológica, neoliberalismo y política penal. Delito y sociedad: Revista de Ciencias Sociales, Buenos Aires, año 10, n. 15/16, p. 141-160, 2001.

PERES-NETO, Luis. Prensa, política criminal y opinión pública: el populismo punitivo en España, Tesis doctoral, Barcelona: Universidad Autónoma de Barcelona, 2010.

PRATT, John. Penal populism. New York: Routledge, 2007.

RIZZINI, Irene; RIZZINI, Irma. A institucionalização de crianças no Brasil: Percurso histórico e desafios do presente. Rio de Janeiro: PUC-Rio; São Paulo: Loyola, 2004.

SARAIVA, João Batista Costa. Compêndio de direito penal juvenil. 4 ed. Porto Alegre: Livraria do Advogado, 2010.

SILVERMAN, Jon. Crime, Policy and the Media: the Shaping of Criminal Justice, 1989-2010. London: Routledge, 2012.

SOZZO, Máximo. Populismo punitivo, proyecto normalizadory "prisión-depósito" en Argentina. Sistema Penal \& Violência, Porto Alegre, v. 1, n.1, p. 33-65, julho-dezembro, 2009.

TAROUCO, Gabriela da Silva; MADEIRA, Rafael Machado. Left and right in the Brazilian party system.XI Congress of the Brazilian Studies Association. 6-8 September 2012. University 
of Illinois at Urbana-Champaign.Disponível em: http://www.brasa.org/documents/brasa_xi/ Gabriela-Tarouco-Rafael-Madeira. pdf. Acesso em: 18 jan. 2013.

WACQUANT, Loïc. Punir os pobres: A nova gestão da miséria nos Estados Unidos. 2. ed. Rio de Janeiro: Revan/ICC, 2003.

WAISELFISZ, JulioJacobo. Mapa da violência 2014: os jovens do Brasil. Rio de Janeiro: FLACSO, 2014. Disponível em: <http://www.mapadaviolencia. org. br/pdf2014/Mapa2014_ JovensBrasil_Preliminar.pdf>. Acesso em: 15 mar. 2015.

ZAFFARONI, E. Raúl; BATISTA, Nilo; SLOKAR, Alejandro; ALAGIA, Alejandro. Direito penal brasileiro. v. I. 2. ed. Rio de Janeiro: Revan, 2003.

ZAFFARONI, Eugenio Raúl. A palavra dos mortos: Conferências de criminologia cautelar. São Paulo: Saraiva, 2012.

\section{NOTA DE FIM}

1 Os projetos sobre medidas socioeducativas trouxeram características diferentes entre si, de modo que se entendeu por bem separá-las em três categorias, conforme se tratem de medidas diferentes da internação (categoria 12), da medida de internação com o intuito de recrudescer o controle e, portanto, reprimir (categoria 13), e da medida de internação para garantir direitos e estabelecer melhoria nas condições de sua execução (categoria 14). Todas se localizam no Título III da Parte Especial do ECA.

Recebido em: mar/2015

Aprovado em: ago/2015 